\title{
Nitrogen and phosphorus management on pig farms in Northwest Germany - nutrient balances and challenges for better sustainability
}

\author{
D. Otten* and H. F. A. Van den Weghe \\ Department of Animal Sciences, Division: Process Engineering, Georg-August University of Goettingen, \\ Universitaetsstr. 7, D-49377 Vechta, Germany.
}

Accepted 26 March, 2013

\begin{abstract}
The study analyses the nutrient flow of nitrogen $(N)$ and phosphorus $(P)$ on six intensive pig farms in Northwest Germany over a period of 5 years. The study investigated the farmers' management of nutrient flows associated with intensive pig farming, focusing especially on the management of manure. It could be shown that in intensive pig production, high performance and performance-related feeding positively affects nutrient flow efficiency. However, on the crop production side of the farms, there existed a great disharmony between the farmers' perception of manure used as $(N, P)$ fertiliser on their crops and the real quantity of nutrients produced by their intensive pig farming. The farmers were unable to estimate the fertiliser effect of their manure correctly [underestimation $N=7.6 \%(10.6 \mathrm{~kg} / \mathrm{ha})$, $\mathrm{P}=33.6 \%(11.6 \mathrm{~kg} / \mathrm{ha})]$. The application of nutrients by mineral fertiliser was underestimated also [ $\mathrm{N}$ by $4.1 \%(8.1 \mathrm{~kg} / \mathrm{ha}), \mathrm{P}$ by $12.7 \%(1.5 \mathrm{~kg} / \mathrm{ha})]$ and were inadequately attuned to the large amount of manure produced by their intensive pig production. As a result, the farms had large nutrient losses (104.5 kg N/ ha; $11.7 \mathrm{~kg} \mathrm{P} / \mathrm{ha}$ ) and were unable to fulfil the minimum German legal requirements for fertiliser application. The study evaluated the critical aspects of nutrient management and discusses possible improvements for the future.
\end{abstract}

Key words: Nutrient management, intensive pig production, Northwest Germany

\section{INTRODUCTION}

Sustainable food production places a great deal of responsibility on farm management to ensure a wellbalanced nutrient flow (Koelsch and Lesoing, 1999). Nutrient management must always be considered with respect to the prevalent production conditions: The farm structure (e.g. husbandry, type of farmland, infrastructure), the biophysical conditions (e.g. climate, soil), the prevalent socio-economic conditions (e.g. availability and cost of intermediate goods or techniques) and other dependent variables. The ideal management strategy always depends on the individual situation (Bosshard, 2000; Koelsch and Lesoing, 1999).

Bearing this in mind, the nutrient flow management in an Intensive Livestock Area (ILA) is associated with exceptional challenges. ILAs are regions with a very high livestock concentration and often also with a higher productivity and degree of business organisation in livestock farming. Pig farms in such regions often have a greater productivity, size and degree of specialisation than farms in other regions. This leads to a higher 
material flow of individual nutrients per farm. In addition, ILAs have a very high regional turnover of nutrients and the excessive production of manure is becoming an increasingly important regional challenge and environmental risk (llea, 2009; Warnecke et al., 2009; Berkhoff, 2005; Abdalla, 2002; Tilman et al., 2002; Wing and Wolf, 2000).

In the past, various authors have concerned themselves with nutrient flows in intensive pig production. Abdalla (2002) has given a general historical overview about the industrialisation of livestock farming and its conflicts and discussed the consequences from a broader institutional economic perspective. Cahoon et al. (1999) described the eutrophication threat to the river basins and other areas with expanding animal populations from the potential large nutrient loadings in North Carolina. Mc Sweeny and Shortle (1989) analysed the fertilisation problems from the perspective of a crop yield response to nitrogen application and the nitrogen content of manure in ILAs. They analysed the effects of various policy prescriptions on fertilisation decisions by such farmers and showed the importance of understanding producer behaviour for the design of economically sound policies.

The $\mathrm{N}$ and $\mathrm{P}$ consumption, utilisation and losses in pig production have also been analysed in the Netherlands (Van der Peet-Schwering et al., 1999; De Boer et al., 1997; Breeuwsma et al., 1995), France (Basset-Mens and Van der Werf, 2005; Dourmad et al., 1999) and Denmark (Nielson and Kristensen, 2005; Fernandez et al., 1999). The various authors evaluated the overall status for reducing the environmental problems associated with pig production by using feeding and other management measures. They also discussed $\mathrm{N}$ and $\mathrm{P}$ management in relation to legislative measures.

Tamminga (2003) described the pollution caused by nutrient losses and its control in European animal production and suggested a combination of a better onfarm nutrient management and a maximum stocking density of 2.0 livestock units / hectare (LU/ha) (LU = livestock units; $1 \mathrm{LU}=500 \mathrm{~kg}$ ). The German Fertiliser Ordinance prescribes this maximum stocking density also. Additionally, a maximum overload (input - output) of $60 \mathrm{~kg} \mathrm{~N} / \mathrm{ha}$ and $20 \mathrm{~kg} \mathrm{P} \mathrm{O}_{5}(8.73 \mathrm{~kg} \mathrm{P}) / \mathrm{ha}$ is allowed. The maximum $\mathrm{N}$ fertilisation for manure is limited to $170 \mathrm{~kg}$ $\mathrm{N} /$ ha [German Fertiliser Ordinance (Düngeverordnung DüV) 2007].

However, because of the dynamic regional concentration processes in ILAs at present and the increased requirements for sustainable animal production, the current development in such regions has to be checked with respect to on-farm material flow management. With this in mind, the present study had the following specific research objectives: (I) to describe the flow of $\mathrm{N}$ and $\mathrm{P}$ through the individual farm materials and identify the important factors affecting efficiency nutrient management; (II) to analyse the nutrient management of great quantities of manure; and (III) to use the results to discuss any possible opportunities to improve nutrient flow management in ILAs.

\section{MATERIALS AND METHODS}

For the investigation, the total $\mathrm{N}$ and $\mathrm{P}$ flow (inputs, intra-farm and outputs) of all the materials on six pig farms [2x piglet production, $2 x$ finishing pig production and $2 x$ combination farms (piglet production and finishing pigs)] were analysed over a period of 5 years. Due to this analysis of real farm data over a number of years, six farms were considered to be an adequate number of probands for a meaningful representation. In addition, it should be mentioned that a great deal of cooperation from the farmers is required to acquire all the data concerning a farm's material flow and the farmer's nutrient management.

The six farms were located in Northwest Germany. Table 1 gives an overview of the average structure of the six farms and information about the average stocking density of the whole region of Northwest Germany over the study period. The abbreviations in front of the farm number represent the type of pig farm: $P P=$ piglet production, $\mathrm{FP}=$ finishing pig production and $\mathrm{CF}=$ combination farm. These abbreviations will be used throughout this paper.

The average number of animals per farm [329 sows (PP + CF); 784 finishing places (FP + CF)] and the concentration of animals per unit area $[2.73 \mathrm{LU} / \mathrm{ha}(1 \mathrm{LU}=500 \mathrm{~kg})]$ of the six farms reflected the regional conditions. Their production was also typical of this region [weaned piglets/ sow and year $=21.9(\mathrm{PP}+\mathrm{CF})$; daily weight increase/ finishing pig $=707 \mathrm{~g}(\mathrm{FP}+\mathrm{CF})]$. The average area of the six farms was 68.4 ha. The crop production primarily involved cereals (36.3 ha), maize (25.6 ha), small amounts of oilseed rape (5.4 ha) and other crops (1.1 ha). The farms' texture of soil was sandy or clayey and of medium quality [German soil quality index = 18-35; scale of index = 7-100 (BodSchätzG, 2007)].

The analyses of the nutrient flow covered all the material inputs, the intra-farm transformations and the material outputs of all the farm's goods. Table 2 provides an overview of the audited materials and the calculations used in the investigation.

The information about the inputs via the animals, feed and mineral fertiliser (the amount used and composition) was provided by the bills of sale from the producer or the supplier/ purchaser. The $\mathrm{N}$ and $\mathrm{P}$ flows of the animals were budgeted according to the German Society of Nutritional Physiology (GfE, 2006). The values for the types and quantity of ammonia depositions in crop production (Builtjes et al., 2011) and the emissions leaving the pig production (Luft, 2002) were taken from other studies carried out in the region.

In addition to the analyses of nutrient flow, the soil of each farm was analysed (VDLUFA, 1991) over a period of 15 years (annual) to determinate its mineral makeup and any changes over time. A total of 15 to 30 samples were taken per ha and were mixed to give one sample. The depth of soil sample corresponded with the ploughing depth on arable land; grassland no ploughing (arable land $=0-30 \mathrm{~cm}$; grassland $0-10 \mathrm{~cm}$ ). The samples were analysed by the Association of German Agriculture Analytic and Research Institutes (VDLUFA 1991) [ISO 11732 and 11885 (2005), DIN 19684 (2000), DIN 38414 (1985)].

The calculation period used for the pig production units was the standard German animal husbandry business year (01 July - 30 June). For the crop production, each individual crop was analysed. The efficiency of the piglet production [output (piglets + slaughter sows) / input (lactation diet + gestation diet + piglet diet + gilts)] and the efficiency of the fattening pig production [output (fattening pigs) / input (fattening diet + piglets)] were calculated. The calculations for the combination farms included both these formulae. The efficiency of the crop production was also calculated [output (primary crops + secondary crops) / input (chemical fertiliser + manure + seeds $+\mathrm{N}$ deposition)] . 
Table 1. Structure of the six farms used in the study [PP: piglet production; FP: fattening pig production; CF: combination (piglets and fattening pigs)]

\begin{tabular}{|c|c|c|c|c|c|c|c|c|c|c|c|c|c|}
\hline \multirow{2}{*}{ Parameter } & & \multicolumn{2}{|c|}{$\mathrm{PP}(\mathrm{I})^{1)}$} & \multicolumn{2}{|c|}{ PP (II) } & \multicolumn{2}{|c|}{ FP (I) } & \multicolumn{2}{|c|}{ FP (II) } & \multicolumn{2}{|c|}{ CF (I) } & \multicolumn{2}{|c|}{ CF (II) } \\
\hline & & Mean & \pm & Mean & \pm & Mean & \pm & Mean & \pm & Mean & \pm & Mean & \pm \\
\hline Region & LU/ha ${ }^{2)}$ & 2.3 & 1 & 2.0 & 1 & 3.4 & 1 & 3.4 & 1 & 3.4 & 1 & 3.4 & 1 \\
\hline Farm & LU/ha & 4.5 & / & 2.0 & / & 3.7 & / & 2.0 & / & 1.6 & / & 2.6 & / \\
\hline Area of farm & ha & 83.3 & 7.2 & 67.6 & 0.3 & 50.1 & 3.1 & 33.7 & 0.8 & 106.8 & 2.5 & 68.9 & 3.5 \\
\hline \multicolumn{14}{|l|}{ Crop production } \\
\hline Cereals & ha & 36.1 & 8.8 & 42.7 & 3.6 & 17.3 & 3.6 & 19.8 & 0.7 & 52.4 & 1.6 & 49.6 & 5.8 \\
\hline Maize & ha & 47.2 & 8.6 & 7 & 4.6 & 29.8 & 2.8 & 12.7 & 1.3 & 46.7 & 3.3 & 10.6 & 5 \\
\hline Oilseed rape & ha & / & I & 16.2 & 2.9 & I & 1 & / & l & 7.7 & 3.9 & 8.2 & 2.5 \\
\hline Other & ha & l & l & 1.8 & 2.6 & 3 & 3.2 & 1.1 & l & / & I & 0.6 & 0.9 \\
\hline \multicolumn{14}{|l|}{ Pig husbandry } \\
\hline Pig breeding & Units & 637.2 & 39 & 236.5 & 9 & & & & & 173.3 & 13.8 & 270.7 & 7.7 \\
\hline Fattening & Units & & & & & 1238 & 19 & 560 & 0 & 1143.3 & 222 & 199 & 18.5 \\
\hline \multicolumn{14}{|l|}{ Production } \\
\hline Weaned piglets & Sow and year & 23.7 & 1.1 & 22.1 & 1 & & & & & 20.8 & 0.4 & 21.1 & 0.6 \\
\hline No. of litters & Sow and year & 2.4 & 0.0 & 2.2 & 0.1 & & & & & 2.6 & 0.4 & 2.3 & 0.03 \\
\hline Body weight increase & g/day & & & & & 713 & 8.9 & 642 & 29 & 786.7 & 7.8 & 684 & 25.6 \\
\hline Finished pigs/ unit & p. a. ${ }^{3)}$ & & & & & 2.6 & 0.1 & 2.4 & 0.1 & 3.1 & 0.0 & 2.8 & 0.1 \\
\hline
\end{tabular}

Particular attention was paid to the farmers' management of their manure. Using a questionnaire about their crop production management, the farmers were asked about how many $\mathrm{kg} \mathrm{N}$ and $\mathrm{P}$ they believed they were applying per hectare to each field. These values were then compared with the true audited amounts from the pig production and the differences determined (Table 2). The differences between the perception of how much $N(\mathrm{~kg} / \mathrm{ha})$ and $P$ $(\mathrm{kg} / \mathrm{ha})$ were applied with mineral fertiliser and the true amount were determined also.

Subsequently, a stepwise linear regression was carried out to determine which factors significantly affected nutrient efficiency in the various forms of production $(P<0.05)$. In this procedure, the factors were implemented until there was no further increase in $R^{2}$. The respective efficiency in the piglet production and the crop production were the independent variables and the different materials included in the nutrient flows the dependent ones. The factors were tested for their statistical significance $(P<0.05)$. The variables were standardised in order to analyse which ones had the greatest influence (standardised beta coefficient). The statistical analysis was carried out with the software program SPSS, Version 19 (PASW Statistics - SPSS 19. for Windows).

\section{RESULTS}

The $\mathrm{N}$ and $\mathrm{P}$ flows and the important factors affecting their efficiency will be described, firstly with respect to the pig production and then to the crop production. Lastly, the farmers' management of the large amount of manure produced by their pig production will be elucidated.

\section{Pig production}

Table 3 illustrates the $\mathrm{N}$ and $\mathrm{P}$ flows in the pig production. The results for each type of pig production system [PP, FP and CF] over the whole study period have been summarised.

The average total annual turnover [total $(\mathrm{N}, \mathrm{P})$ input; total $(\mathrm{N}, \mathrm{P})$ output] per sow in the piglet production varied between $54.7 \mathrm{~kg}$ (PP) and $54.9 \mathrm{~kg}$ (CF) for $\mathrm{N}$, and between $10.5 \mathrm{~kg}$ (PP) and $10.6 \mathrm{~kg}$ (CF) for P. The average values per unit (place) in the finishing pig production ranged from $17.7 \mathrm{~kg}$ (CF) to $18.0 \mathrm{~kg}(\mathrm{FP})$ for $\mathrm{N}$ and $3.3 \mathrm{~kg}$ (FP) to $3.4 \mathrm{~kg}$ (CF) for $P$. The manure production was between $29.3 \mathrm{~kg} \mathrm{~N} /$ sow (PP) and $29.6 \mathrm{~kg}$ $\mathrm{N} /$ sow (CF) and $6.8 \mathrm{~kg} \mathrm{P} /$ sow (PP) and 7.0 (CF) kg P/ sow in the piglet production and $7.2 \mathrm{~kg} \mathrm{~N} /$ unit (FP) to 7.6 $\mathrm{kg} \mathrm{N} /$ unit (CF) and $2.0 \mathrm{~kg} \mathrm{P} /$ unit (FP) to $2.2 \mathrm{~kg} \mathrm{P} /$ unit (CF) in the finishing pig production. The efficiency in the piglet production $[\mathrm{N}=0.35(\mathrm{PP})$ to $0.34(\mathrm{CF}) ; \mathrm{P}=0.34$ $(\mathrm{PP})$ to $0.33(\mathrm{CF})]$ was lower than in the finishing pig production $[\mathrm{N}=0.39(\mathrm{FP})$ to $0.36(\mathrm{CF}) ; \mathrm{P}=0.39(\mathrm{FP})$ to $0.34(\mathrm{CF})]$.

In the piglet production, the $\mathrm{N}$ and $\mathrm{P}$ concentrations of the different diets were rather similar on all six farms (Table 3). This is typical of intensive pig farming in Northwest Germany as all the diets were industrially produced. Since the mounting intensification of livestock 
Table 2. The audited materials, the data sources and the calculations used in the inventory.

\begin{tabular}{ll}
\hline Material & Kind of calculation \\
\hline Diets & $\begin{array}{l}\text { Bill of sale from producer or supplier } \\
\text { about amount and concentrations }\end{array}$ \\
& \\
Information from farmer (bill of sale) for \\
number and weight of pigs. Then GfE \\
2006 to calculate nutrient flow \\
Animals \\
\\
\\
\\
\\
$\begin{array}{l}\text { Primary } \\
\text { crops,secondary } \\
\text { crops, seeds }\end{array}$ \\
$\begin{array}{l}\text { Information from producer or distributor } \\
\text { about quantity (bill of sale). Then German } \\
\text { Fertiliser Ordinance [Düngeverordnung - } \\
\text { (DüV), 2007] to calculate nutrient flow (in } \\
g / k g)\end{array}$ \\
$\begin{array}{l} \\
\end{array}$ \\
\end{tabular}

\section{Data}

Average amounts and concentrations (Table 3)

Protein quantity $(\mathrm{kg} / \mathrm{pig}):<30 \mathrm{~kg}$ body weight $=169 \mathrm{~g} / \mathrm{kg}$ body weight; $>30 \mathrm{~kg}$ bodyweight $=0.168 \times$ body weight $0.0000914 \times$ body weight ${ }^{2}$

$\mathrm{P}$ quantity (kg/pig): $<80 \mathrm{~kg}$ bodyweight $=5.0 \mathrm{~g} / \mathrm{kg}$ bodyweight; $>80 \mathrm{~kg}$ body weight $=4.5 \mathrm{~g} / \mathrm{kg}$ body weight

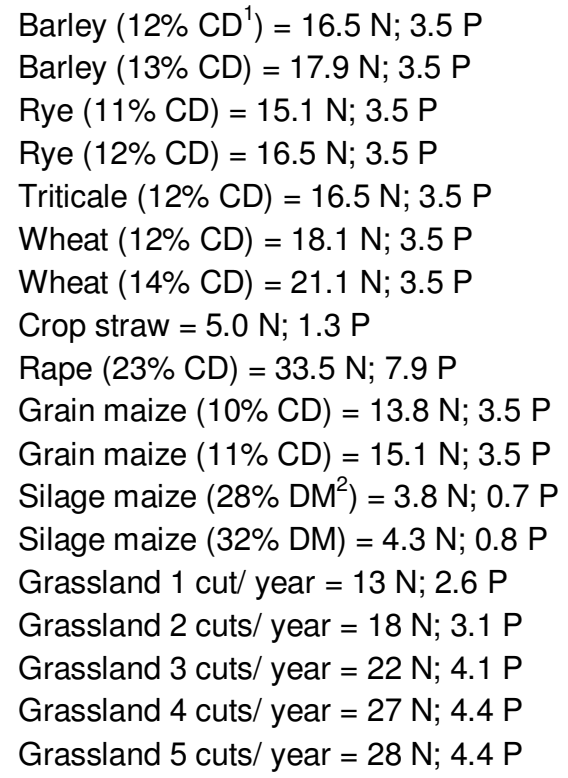

Average amounts and concentrations (Table 3) about amount and product contents

Mineral fertiliser

Piglet production $=6.0 \mathrm{~kg} \mathrm{~N} /$ sow (piglet production only) Fattening pig production $=3.6 \mathrm{~kg} \mathrm{~N} /$ unit

\section{$55 \mathrm{~kg} \mathrm{~N} / \mathrm{ha}$}

Input (mineral fertiliser + manure + seeds + deposition) Output (primary + secondary crops)

Input [different diets + animal inputs (piglets or gilts)] Outputs: [animal outputs (sold animals and losses) + N emissions].

For Input crop production: - (10\% N pit losses) - $(20 \% \mathrm{~N}$ losses during manure application)

${ }^{1)} \mathrm{CD}=$ Crude Protein; ${ }^{2)} \mathrm{DM}=$ Dry Matter.

production in the mid-1990s, the farms have increasingly used crude-protein (CP) and phosphorus-reduced diets in order to reduce both $\mathrm{N}$ and $\mathrm{P}$ in the manure and the amount of ammonia emitted. The highest concentrations in the diets used on the six farms were lactation diet $\mathrm{CP}<$ $16.5 \%, \mathrm{P}<0.55 \%$; gestation diet $=\mathrm{CP}<14 \%, \mathrm{P}<$ $0.45 \%$; and piglet diet $=\mathrm{CP}<18 \%, \mathrm{P}<0.55 \%$.

Because of the similar concentrations in the different 
Table 3. The average (mean, SD) nitrogen $(\mathrm{N})$ and phosphorus $(\mathrm{P})$ flow in the animal production with their respective quantities $(\mathrm{kg})$ and concentrations ( $\mathrm{g} / \mathrm{kg}$ ) over the whole study period.

\begin{tabular}{|c|c|c|c|c|c|c|c|c|c|c|c|c|c|c|c|c|c|c|c|}
\hline \multirow{4}{*}{$\begin{array}{l}\text { Element } \\
\text { Input }\end{array}$} & \multirow{4}{*}{ Unit } & \multicolumn{6}{|c|}{ Piglet production (PP) } & \multicolumn{6}{|c|}{ Fattening pig production (FP) } & \multicolumn{6}{|c|}{ Combination farm (CF) } \\
\hline & & \multicolumn{4}{|c|}{ Amount } & \multirow{2}{*}{\multicolumn{2}{|c|}{$\begin{array}{l}\text { Concentration in } \\
\text { product }(\mathrm{g} / \mathrm{kg})\end{array}$}} & \multicolumn{4}{|c|}{ Amount } & \multirow{2}{*}{\multicolumn{2}{|c|}{$\begin{array}{l}\text { Concentration in } \\
\text { product }(\mathrm{g} / \mathrm{kg})\end{array}$}} & \multicolumn{4}{|c|}{ Amount } & \multirow{2}{*}{\multicolumn{2}{|c|}{$\begin{array}{c}\text { Concentration in } \\
\text { product }(\mathrm{g} / \mathrm{kg})\end{array}$}} \\
\hline & & \multicolumn{2}{|c|}{$\mathbf{N}$} & \multicolumn{2}{|c|}{$\mathbf{P}$} & & & \multicolumn{2}{|c|}{$\mathbf{N}$} & \multicolumn{2}{|c|}{$\mathbf{P}$} & & & \multicolumn{2}{|c|}{$\mathrm{N}$} & \multicolumn{2}{|l|}{$\mathbf{P}$} & & \\
\hline & & $\mu^{1)}$ & \pm & $\mu$ & \pm & $N$ & $P$ & $\mu$ & \pm & $\mu$ & \pm & $N$ & $P$ & $\mu$ & \pm & $\mu$ & \pm & $N$ & $P$ \\
\hline Lactation diet & $\mathrm{kg} / \mathrm{sow}$ & 11.2 & 2.2 & 5.3 & 1.1 & 26.8 & 12.6 & & & 54.9 & 17.7 & 24.2 & 7.8 & 7.6 & 1.7 & 3.6 & 0.8 & 26.4 & 12.4 \\
\hline Gestation diet & $\mathrm{kg} / \mathrm{sow}$ & 20.4 & 5.2 & 9.5 & 2.4 & 22.7 & 10.4 & & & & & & & 23.9 & 2.1 & 10.8 & 0.7 & 22.8 & 10.3 \\
\hline Piglet diet & $\mathrm{kg} / \mathrm{sow}$ & 21.9 & 1.6 & 8.7 & 0.7 & 28.0 & 12.6 & 18.0 & & 7.7 & & & & 22.4 & 2.7 & 9.4 & 0.8 & 27.9 & 11.8 \\
\hline Fattening diet & $\mathrm{kg} / \mathrm{unit}$ & & & & & & & 15.9 & 0.9 & 6.8 & 0.3 & 24.9 & 10.7 & 15.6 & 1.7 & 6.9 & 0.7 & 26.1 & 11.6 \\
\hline Gilts & $\mathrm{kg} / \mathrm{sow}$ & 1.2 & 0.2 & 0.5 & 0.1 & 24.5 & 10.3 & & & & & & & 1.0 & 0.3 & 0.4 & 0.1 & 24.6 & 10.3 \\
\hline Piglets & $\mathrm{kg} / \mathrm{unit}$ & 54.7 & & 24.0 & & & & 2.1 & 0.1 & 0.8 & 0.1 & 26.9 & 11.5 & 2.1 & 0.4 & 0.9 & 0.2 & 26.9 & 11.5 \\
\hline Output & total $(\mathrm{kg})$ & 54.7 & & 24.0 & & & & 18.0 & & 7.7 & & & & 72.6 & 2) & 32.1 & 2) & & \\
\hline Fattening pigs & kg/unit & & & & & & & 7.0 & 0.3 & 3.0 & 0.1 & 24.2 & 10.3 & 6.3 & 1.0 & 2.7 & 0.4 & 24.2 & 10.3 \\
\hline Piglets & $\mathrm{kg} / \mathrm{sow}$ & 17.2 & 0.7 & 7.3 & 0.3 & 26.9 & 11.5 & & & & & & & 17.2 & 1.8 & 7.3 & 0.8 & 26.9 & 11.5 \\
\hline Slaughter sows & $\mathrm{kg} / \mathrm{sow}$ & 1.9 & 0.2 & 0.9 & 0.1 & 23.1 & 10.3 & & & & & & & 1.7 & 0.4 & 0.8 & 0.2 & 23.0 & 10.3 \\
\hline A nim & $\mathrm{kg} / \mathrm{sow}$ & 0.3 & 0.1 & 0.1 & 0.0 & 25.1 & 11.1 & & & & & & & 0.4 & 0.1 & 0.2 & 0.0 & 25.0 & 10.9 \\
\hline Animal & $\mathrm{kg} / \mathrm{unit}$ & & & & & & & 0.1 & 0.03 & 0.05 & 0.01 & 26.3 & 11.5 & 0.1 & 0.0 & 0.0 & 0.0 & 26.2 & 11.5 \\
\hline Manuro & $\mathrm{kg} / \mathrm{sow}$ & 29.3 & & 15.6 & 1.3 & 3.0 & 1.3 & & & & & & & 29.6 & & 15.9 & 0.9 & 4.4 & 1.6 \\
\hline IVlanure & $\mathrm{kg} / \mathrm{unit}$ & & & & & & & 7.2 & & 4.6 & 0.3 & 5.8 & 4.1 & 7.6 & & 5.1 & 0.8 & 4.5 & 2.3 \\
\hline Ammonia & $\mathrm{kg} / \mathrm{sow}$ & 6.0 & & & & & & 10.8 & & 3.0 & & & & 6.0 & & & & & \\
\hline emissions & $\mathrm{kg} / \mathrm{unit}$ & 25.4 & & 8.3 & & & & 3.6 & & & & & & 3.6 & \# & 10.1 & 8.3 & 2.7 & \\
\hline Efficiency & Total (kg) & 54.7 & & 24.0 & & & & 18.0 & & 7.7 & & & & 72.6 & 2) & 32.1 & 2) & & \\
\hline Efficiency (PP) ${ }^{3)}$ & & 0.35 & & 0.34 & & & & & & & & & & 0.34 & & & & & \\
\hline Efficiency (FP) 4) & & & & & & & & 0.39 & & 0.39 & & & & 0.36 & & 0.34 & & & \\
\hline Total animal produ & tion efficiency & 0.35 & & 0.34 & & & & 0.39 & & 0.39 & & & & 0.35 & & 0.34 & & & \\
\hline
\end{tabular}

${ }^{\text {1) }}=$ Means ${ }^{2)}=$ Total Inputs and Outputs in CF: piglet production (PP): $=54.9 \mathrm{~kg} \mathrm{~N}, 24.2 \mathrm{~kg} \mathrm{P}$; fattening pig production $17.7 \mathrm{~kg} \mathrm{~N}, 7.9 \mathrm{~kg} \mathrm{P}{ }^{3)}=$ Output (piglets + slaughter sows) Input (lactation diet + gestation diet + piglet diet + gilts $) ;{ }^{4}=$ Output $=$ (fattening pigs) $/$ Input $=$ (fattening diet + piglets)

diets used on the farms, the stepwise regression showed that it was particularly the farmers' feeding management of the different diets which affected the nutrient efficiency [(Model $N$ efficiency: $Y=-1.434{ }^{*}$ gestation diet $-0.746{ }^{*}$ lactation diet $-0.347^{*}$ piglet diet, $R^{2}=0.95 ; P$ efficiency model: $Y=-1.664$ * gestation diet -1.067 * lactation diet -0.418 * piglet diet, $\left.R^{2}=0.85\right]$. There was a lower use of gestation diet (from $40 \mathrm{~g}$ down to $25 \mathrm{~g} \mathrm{~N} / \mathrm{kg}$ produced piglet and from $8.5 \mathrm{~g}$ down to $5.0 \mathrm{~g} \mathrm{P} /$ $\mathrm{kg}$ produced piglet) and a higher use of lactation diet (from $13.0 \mathrm{~g}$ up to $20.0 \mathrm{~g} \mathrm{~N} / \mathrm{kg}$ produced 


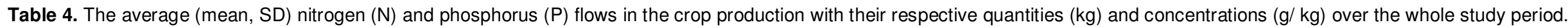

\begin{tabular}{|c|c|c|c|c|c|c|c|c|c|c|c|c|c|c|c|c|c|c|c|}
\hline \multirow{4}{*}{$\begin{array}{l}\text { Material } \\
\text { Input }\end{array}$} & \multirow{4}{*}{ Unit } & \multicolumn{6}{|c|}{ Piglet production (PP) } & \multicolumn{6}{|c|}{ Fattening pig production (FP) } & \multicolumn{6}{|c|}{ Combination Farm (CF) } \\
\hline & & \multicolumn{4}{|c|}{ Amount } & \multirow{2}{*}{\multicolumn{2}{|c|}{$\begin{array}{c}\text { Concentration } \\
(g / \mathrm{kg})\end{array}$}} & \multicolumn{4}{|c|}{ Amount } & \multirow{2}{*}{\multicolumn{2}{|c|}{$\begin{array}{c}\text { Concentration } \\
(\mathrm{g} / \mathrm{kg})\end{array}$}} & \multicolumn{4}{|c|}{ Amount } & \multirow{2}{*}{\multicolumn{2}{|c|}{$\begin{array}{c}\text { Concentration } \\
(\mathrm{g} / \mathrm{kg})\end{array}$}} \\
\hline & & \multicolumn{2}{|c|}{$\mathbf{N}$} & \multicolumn{2}{|c|}{$\mathbf{P}$} & & & \multicolumn{2}{|c|}{$\mathbf{N}$} & \multicolumn{2}{|c|}{$\mathbf{P}$} & & & \multicolumn{2}{|c|}{$\mathbf{N}$} & \multicolumn{2}{|c|}{$\mathbf{P}$} & & \\
\hline & & $\mu 1)$ & \pm & $\mu$ & \pm & $N$ & $P$ & $\mu$ & \pm & $\boldsymbol{\mu}$ & \pm & $N$ & $P$ & $\mu$ & \pm & $\mu$ & \pm & $N$ & $P$ \\
\hline Chemical fertiliser & $\mathrm{kg} / \mathrm{ha}$ & 100.6 & 36 & 6.6 & 4.4 & 257.8 & 20.4 & 52.8 & 11.8 & 6.9 & 3.2 & 231.8 & 30.4 & 107.2 & 30.5 & 5.1 & 1.7 & 182.8 & 10.8 \\
\hline Manure & $\mathrm{kg} / \mathrm{ha}$ & 85.0 & 11.7 & 33.8 & 5.1 & 3.0 & 0.6 & 85.3 & 27 & 36.6 & 6.7 & 5.8 & 1.8 & 100.6 & 7.77 & 36.2 & 1.5 & 4.4 & 0.7 \\
\hline Seeds & $\mathrm{kg} / \mathrm{ha}$ & 1.6 & 0.3 & 0.3 & 0.1 & 17.0 & 3.5 & 1.4 & 0.4 & 0.3 & 0.1 & 15.8 & 3.2 & 1.6 & 0.2 & 0.3 & 0.0 & 17.1 & 3.5 \\
\hline $\mathrm{N}$ depositions & $\mathrm{kg} / \mathrm{ha}$ & 55.0 & & & & & & 55.0 & & & & & & 55.0 & & & & & \\
\hline Output & Total $(\mathrm{kg})$ & 242.2 & & 40.7 & & & & 194.5 & & 43.7 & & & & 264.4 & & 41.6 & & & \\
\hline Primary crops & $\mathrm{kg} / \mathrm{ha}$ & 106.1 & 13.3 & 23.9 & 3.1 & 16.6 & 3.7 & 108.1 & 16.2 & 25.1 & 3.9 & 9.7 & 2.0 & 130.5 & 12.6 & 28.0 & 2.3 & 0.0 & 25.6 \\
\hline Secondary crops ${ }^{2)}$ & $\mathrm{kg} / \mathrm{ha}$ & 12.6 & 6.6 & 3.8 & 1.4 & 0.6 & 0.2 & 12.1 & 3.3 & 3.2 & 0.8 & 0.6 & 0.2 & 18.1 & 2.2 & 4.7 & 0.5 & 12.2 & 4.0 \\
\hline $\begin{array}{l}\text { Losses and accumulations } \\
\text { in soil }\end{array}$ & $\mathrm{kg} / \mathrm{ha}$ & 123.6 & & 13.0 & & & & 74.2 & & 15.4 & & & & 115.8 & & 8.9 & & & \\
\hline Efficiency & Total $(\mathrm{kg})$ & 242.2 & \# & 40.7 & 27. & & & 194.5 & 12 & 43.7 & 28. & & & 264.4 & \#\# & 41.6 & 3.7 & & \\
\hline Total crop production efficien & & 0.49 & & 0.68 & & & & 0.62 & & 0.65 & & & & 0.56 & & 0.79 & & & \\
\hline
\end{tabular}

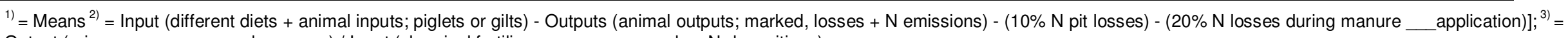
Output (primary crops + secondary crops) / Input (chemical fertiliser + manure + seeds + N-depositions).

piglet and from $2.9 \mathrm{~g}$ up to $3.2 \mathrm{~g} \mathrm{P} / \mathrm{kg}$ produced piglet) on the farms with a high nutrient efficiency. With the piglet diet, $35 \mathrm{~g} \mathrm{~N}$ and $6.9 \mathrm{~g} \mathrm{P}$ was needed for each $\mathrm{kg}$ produced piglet.

In the fattening pig production, the diets were different between the farms and their average $\mathrm{N}$ and $\mathrm{P}$ concentrations had a greater importance for nutrient efficiency than the feed conversion: Model $N$ efficiency: $Y=-0.894{ }^{*} N$ amount in diet $-0.401{ }^{*}$ feed conversion, $\mathrm{R}^{2}=0.89$; Model $P$ efficiency: $\mathrm{Y}=-0.881$ ${ }^{*} P$ amount in diet $-0.453{ }^{*}$ teed conversion, $R^{2}=0.89$. With an average concentration of $\mathrm{N}=25.5 \mathrm{~g} / \mathrm{kg}$ and $\mathrm{P}=$ $4.8 \mathrm{~g} / \mathrm{kg}$, the more efficient farms had lower average dietary concentrations of both $\mathrm{N}$ and $\mathrm{P}$ than the less efficient farms $(\mathrm{N}=27.9 \mathrm{~g} / \mathrm{kg}, \mathrm{P}=$ $5.1 \mathrm{~g} / \mathrm{kg}$ ). As in the piglet production, those factors which affected the $\mathrm{N}$ efficiency were rather similar to those affected the P efficiency.

\section{Crop production}

The material flow of the crop production on the six pig farms and their $\mathrm{N}$ and $\mathrm{P}$ quantities $(\mathrm{kg})$ and concentrations $(\mathrm{g} / \mathrm{kg})$ are shown in Table 4. The average total annual turnover [total (N, P) input; total $(\mathrm{N}, \mathrm{P})$ output] per ha in the crop production over the whole study period lay between $233.7 \mathrm{~kg}$ $\mathrm{N} / \mathrm{ha}$ and $42.3 \mathrm{~kg} \mathrm{P} / \mathrm{ha}$, with an efficiency of 0.55 for $N$ and 0.69 for $P$. The differences between the different production systems (PP, FP, CP) were not significant. The input via mineral fertilisers was
$86.9 \mathrm{~kg} \mathrm{~N}$ and $6.1 \mathrm{~kg} \mathrm{P}$ per ha. On average, 90.3 $\mathrm{kg} \mathrm{N}$ and $35.5 \mathrm{~kg} \mathrm{P}$ per ha was applied via manure. The average audited losses lay at 104.5 $\mathrm{kg} \mathrm{N}$ and $11.7 \mathrm{~kg} \mathrm{P}$ per ha and year. For the analysis of the factors affecting the nutrient efficiency in the crop production, the $\mathrm{N}$ and $\mathrm{P}$ flows will be described separately.

\section{$\mathrm{N}$ flows}

The stepwise regression showed that it was the inputs which particularly affected the $\mathrm{N}$ efficiency: Model $N$ efficiency: $Y=-0.508 *$ manure -0.449 * mineral fertiliser $+0.286{ }^{*}$ primary crops $\left(R^{2} 0.87\right)$. Figure 1 shows how the fertilisation affected the $\mathrm{N}$ overload 


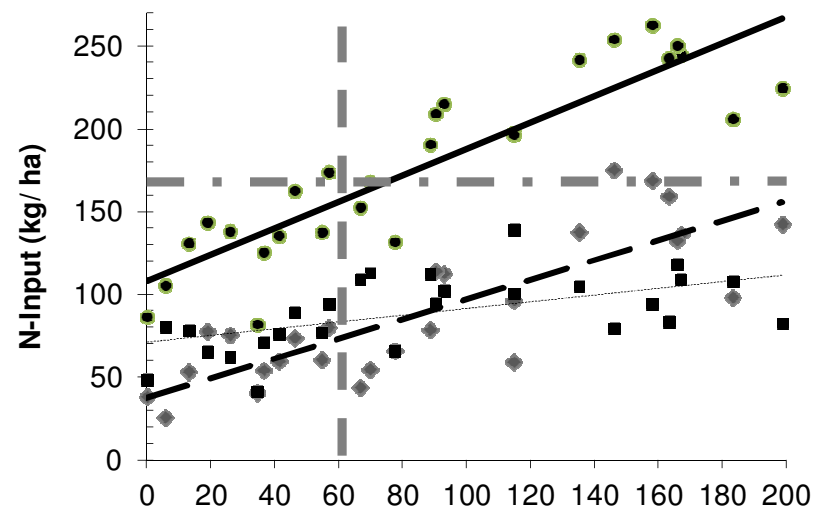

kg N Overload/ ha (total Input - total Output)

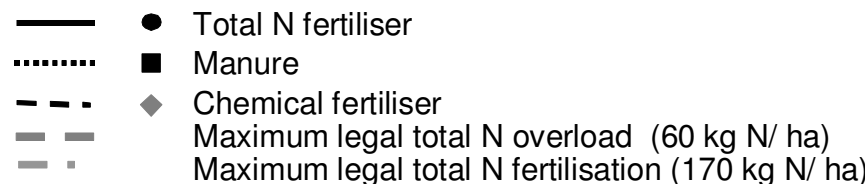

Figure 1. Nitrogen $(\mathrm{N})$ fertilisation on the farms $(\mathrm{kg} / \mathrm{ha})$ and the legal thresholds for the maximum overload and maximum total fertilisation in Germany [German Fertiliser Ordinance (Düngeverordnung-DüV, 2007)].

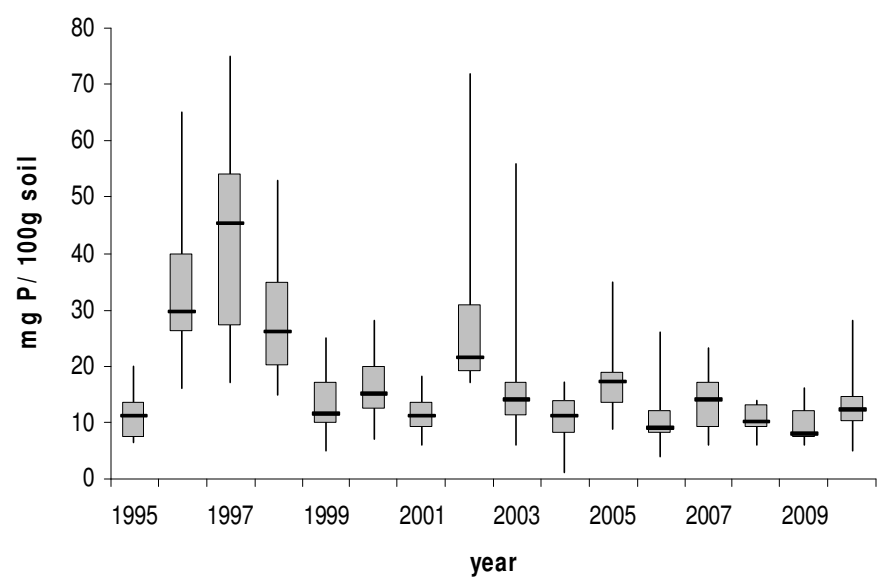

Figure 2. Development of the soil $P$ concentration (mg P/100 g soil) (median, $75 \%$ quartile, $25 \%$ quantile; maximum. minimum) on all 6 farms between 1995 and 20010 .

(losses). The figure also shows the thresholds for maximum $\mathrm{N}$ overload (loss) and $\mathrm{N}$ fertilisation (maximum) given by the German Fertiliser Ordinance (Düngeverordnung - DüV, 2007).

There was a great deal of variation in the amount of $\mathrm{N}$ applied. The two legal thresholds overlap almost exactly by the total $\mathrm{N}$ input line. Taking the standard method of fertiliser application on the farms into consideration, whereby there is a large input of chemical fertiliser, only a very small amount of manure can actually be applied to the fields before the legal thresholds are exceeded. Looking at the intersection of the legal overload threshold and taking into consideration the farmers' style of applying fertiliser, a maximum of $67 \mathrm{~kg} \mathrm{~N} / \mathrm{ha}$ can be applied with chemical fertiliser in addition to $73 \mathrm{~kg} \mathrm{~N} / \mathrm{ha}$ using manure (max. $140 \mathrm{~kg} / \mathrm{ha}$ ).

\section{P flows}

The $\mathrm{P}$ supply within the soil and its development over time is an important indicator for the evaluation of the $P$ flow. Figure 2 shows the $P$ supply on the six farms over a period of 15 years (1995-2009). It became obvious that in the mid-1990s the intensification of pig production led to a high accumulation of $P$ in the soil. Since then, the soil $P$ concentrations have been reduced over time so that they have almost reached optimum values at present ( $6 \mathrm{mg}$ to $12 \mathrm{mg} / 100 \mathrm{~g}$ soil; Fleischer 1998). In addition to the reduction in the mean $\mathrm{P}$ load of the farmland, there has also been a strong reduction in the variation (that is, standard deviation) in $\mathrm{P}$ load so that the farms have achieved a more uniform $P$ condition in their soils.

Looking at the correlations of the P load in the soil with the distance of the field from the livestock buildings (Table 5), it is apparent that in the 1990s the P supply within the soil was closely related to how near it was situated to the farm buildings: The manure was not distributed over the whole farm land evenly. With the intensification of animal production, the farmers tended to apply the manure to the closest fields, while the fields further away evinced little pollution. Table 5 shows the correlation between the distance of the fields from the farm buildings and the $\mathrm{P}$ concentration between the years 1995 to 2009. The regressions make clear that the $P$ concentration in soil has been improved; however, there is still a significant correlation between the distance of the field and the soil $\mathrm{P}$ concentration at present [(2007 2009) $=R^{2}$ 0.19].

For the present-day P efficiency in the crop production, the stepwise regression showed that the nutrient efficiency was especially affected by the inputs. $P$ efficiency model: $Y=-0.677^{*}$ manure $+0.474^{*}$ secondary crops $+0.187^{*}$ primary crops $\left(R^{2} 0.91\right)$. It is obvious that, as with the $\mathrm{N}$ efficiency, manure management had the greatest influence. In contrast to the $\mathrm{N}$ efficiency, however, the mineral fertiliser was not included in the stepwise regression. Figure 3 shows how the $\mathrm{P}$ fertilisation affected the $P$ losses (overload). The minimum legal requirements in Germany are also illustrated [German Fertiliser Ordinance (Düngeverordnung-DüV, 2007].

With a legal maximum threshold overload of $20 \mathrm{~kg} \mathrm{P}_{2} \mathrm{O}_{5}$ $(8.72 \mathrm{~kg} \mathrm{P})$, the farms can apply a total of $39.1 \mathrm{~kg} \mathrm{P} / \mathrm{ha}$. At this threshold and the farmers' present fertilisation practices, $33.2 \mathrm{~kg} \mathrm{P}$ could be applied using manure and $5.9 \mathrm{~kg} \mathrm{P} / \mathrm{ha}$ using chemical fertiliser. 


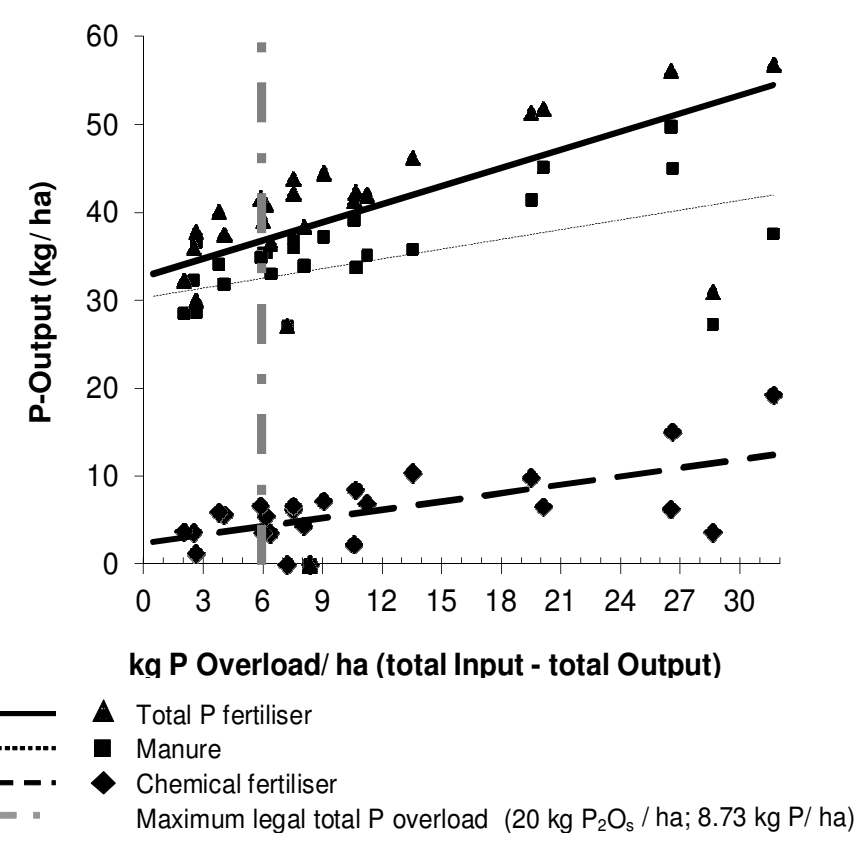

Figure 3. Phosphorus $(P)$ fertilisation on the farms (kg/ ha) and the legal thresholds for the maximum overload in Germany [German Fertiliser Ordinance (Düngeverordnung-DüV) 2007)].

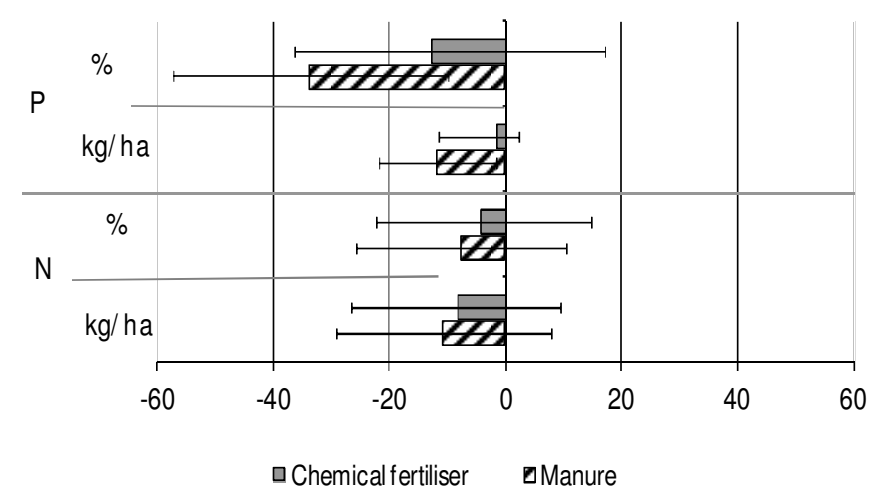

Figure 4. The underestimation of the nutrient application by chemical fertiliser and manure. Shown are the differences (\% total, $\mathrm{kg} / \mathrm{ha}$ ) in perception between the farmers' declared fertiliser use and their true fertiliser use (mean, sd).

\section{The farmers' perception of their application of} nutrient via manure and/or mineral fertiliser

From the crop production information, it is clear that the manure applications were very important for the nutrient efficiency. Figure 4 shows the differences between the $\mathrm{N}$ and $P$ quantities the farmers thought they had applied via manure and the true calculated quantity produced by the pig production. The figure shows also the differences between the farmer's estimation of $\mathrm{N}$ and $\mathrm{P}$ application by mineral fertiliser and the applied amount.
Both the absolute differences ( $\mathrm{kg} / \mathrm{ha})$ and the percentage differences (\%) are illustrated. The figure summarises the information from all six farms over the whole study period.

It is clear that the quantity of nutrient fertilisation manure and mineral fertilisers - was underestimated. The farmers were unable to estimate the fertiliser effect of their manure correctly [underestimation $\mathrm{N}=7.6 \%$ (10.6 $\mathrm{kg} / \mathrm{ha}) \mathrm{P}=33.6 \%(11.6 \mathrm{~kg} / \mathrm{ha})]$. The application of nutrients by mineral fertiliser was underestimated also [N $=4.1 \%(8.1 \mathrm{~kg} / \mathrm{ha}) \mathrm{P}=12.7 \% \quad(1.5 \mathrm{~kg} / \mathrm{ha})]$. The differences between the farms were not significant. The high degree of standard deviation seen emphasises the high potential for improvement in the farmers' estimation of their fertiliser use.

\section{DISCUSSION}

The intensive pig production on the six farms had positive effects on the nutrient efficiency in their livestock farming. As in other studies (Aarnink and Verstegen, 2007; Fernandez et al., 1999; De Boer et al., 1997), it was particularly the high performance and the requirementrelated diets which affected the nutrient efficiency positively. Industrially produced diets with reduced crude protein and $P$ contents or with supplements for better digestibility have been used for a long time in intensive pig production (Aanrink and Verstegen, 2007; De Fernandez et al., 1999; De Boer et al., 1997). The present study has been able to show that the farmers' feeding management has the potential to improve nutrient efficiency even further.

Reducing $\mathrm{P}$ concentration in diets, strongly regulations (and controls of them) and strict fertilizing management were important factors for reducing the $\mathrm{P}$ load in soil in the past (Fernandez et al., 1999; De Boer et al., 1997). Additionally, the increased cultivation of maize could be responsible for partly reduction. The cultivation of barley and rye were replaced by maize at this time very much. On average, maize requires a little more phosphorus of growth. Because of a further reduction of $\mathrm{P}$ load is unnecessary in many places, the question arises as how much more $P$ needs to be removed from diet. This reduction in $\mathrm{P}$ enables the farmers to have a higher stocking density and still be able to conform to the legislative requirements given by the German Fertiliser Ordinance (Düngeverordnung-DÜV, 2007). From a sustainable point of view, the removal of $P$ from the input side of animal production (that is, the diet) is questionable because it can only be done by using (energy-) costly methods and then any necessary $P$ would have to be reapplied to the farm using by mineral fertiliser.

As in other studies in ILAs (Cahoon et al., 1999; Breeuwsma et al., 1995), there was a high accumulation of $P$ in soil on the study farms with the increasing intensification of animal production in the middle of the 1990s. The high influence of the distance of the fields 
Table 5. Development of the relationship between the distance of the fields from the farm buildings and the soil phosphorus concentration (mg P/ $100 \mathrm{~g}$ soil) between the years $1995-2009$.

\begin{tabular}{|c|c|c|c|c|}
\hline Year & $\begin{array}{c}\text { regression function } \\
y=m x+b\end{array}$ & $\mathbf{R} 2$ & $\mathbf{F}$ & sig. \\
\hline $1995-1997$ & {$[-] 2.1854 x \quad[+] \quad 34.09$} & 0.18 & 12.01 & 0.001 \\
\hline $1998-2000$ & {$[-] 0.4363 x \quad[+] \quad 14.20$} & 0.09 & 3.84 & 0.035 \\
\hline $2001-2003$ & {$[-] 0.6405 x \quad[+] \quad 18.10$} & 0.04 & 2.13 & 0.150 \\
\hline $2004-2006$ & {$[-] 0.4984 x \quad[+] \quad 18.32$} & 0.08 & 6.91 & 0.100 \\
\hline $2007-2009$ & {$[-] 0.4857 x \quad[+] \quad 11.91$} & 0.19 & 10.4 & 0.002 \\
\hline
\end{tabular}

from the farm buildings on the soil $P$ concentration in the 1990s illustrated that with any increase intensification of pig production, emphasis should not only be placed on the application technique (e.g. towing hose, direct incorporation into the soil, etc.) as had been done by the local government in Northwest Germany (Ministry of Food, Agriculture, Consumer Protection and Regional Development, Lower Saxony, 2012). Appropriate technologies are also necessary in overcoming longer transportation distances of manure.

The present study had shown that there is a great potential for improving the nutrient efficiency in crop production, too. Particularly, the contribution of the animal production (via the manure) to the nutrient supply in the crop production was not being taken enough into consideration with respect to determining the need for the mineral fertiliser input. This led to particularly high losses both of $N(104.5 \mathrm{~kg} / \mathrm{ha})$ and $P(11.7 \mathrm{~kg} / \mathrm{ha})$. With the present practise of fertiliser application on the study farms, a maximum of $68 \mathrm{~kg} \mathrm{~N} / \mathrm{ha}$ could be applied by chemical fertiliser and $76 \mathrm{~kg} \mathrm{~N} / \mathrm{ha}$ by manure to fulfil the legislative requirements of the German Fertiliser Ordinance (Figure 1). Using these values for the maximum fertiliser production $(29.45 \mathrm{~kg} \mathrm{~N} / \mathrm{sow}$ and 6.05 $\mathrm{kg} \mathrm{N} / \mathrm{unit}$ fattening pig), the maximum stocking density would have to be at 2.3 sows/ ha or 11.2 units fattening pigs/ha $(0.97 \mathrm{LU} / \mathrm{ha}$ for sows or $1.79 \mathrm{LU} /$ ha for fattening pigs; sow including piglet rearing $=0.42 \mathrm{LU}$; fattening pig $=0.16 \mathrm{LU})$. With respect to the requirements of $\mathrm{P}$ fertilisation (overload $=20 \mathrm{~kg} \mathrm{P}_{2} \mathrm{O}_{5} ; 8.72 \mathrm{~kg} \mathrm{P}$ ) a maximum of $33.2 \mathrm{~kg} \mathrm{P} / \mathrm{ha}$ could be applied by manure (Figure 3). This corresponds to an equivalent of 4.8 sows/ ha (production $=6.9 \mathrm{~kg} \mathrm{~N} / \mathrm{sow}$ ) and 15.8 units/ ha (production $=2.1 \mathrm{~kg} \mathrm{P} / \mathrm{unit}$ ) or $2.0 \mathrm{LU} / \mathrm{ha}$ for sows and 2.5 LU/ha for fattening pigs.

These calculations of the maximum stocking density at the farms' present practise of fertiliser application show that the main limiting factor is $\mathrm{N}$. This means that the present practise of fertilisation and the large mineral fertiliser inputs are not compatible with the stocking density on any of the six farms. The underestimations in perception of the fertiliser application illustrated in this investigation emphasise the large managerial mistakes being made in the crop production.
Increasing ecological problems from pig production are also resulting at present from excessive $\mathrm{N}$ depositions from animal husbandry units. Current values are already at $55 \mathrm{~kg} / \mathrm{ha}$ (Builtjes et al., 2011). Beside the depositions caused by manure application, the exhaust air from livestock buildings is the most important form of $\mathrm{N}$ emission (Dämmgen, 2009). Mitigating such emissions is associated with a lot more costs and must be combined with regulatory measures. A major challenge of the future will be to prevent or reduce these emissions.

The present investigation has shown that with respect to sustainable development particular attention needs to be paid to nutrient management practises on the crop side. Even when economic advantages lie in the production of animals in ILAs, the great amount of manure produced makes it necessary that a high degree of managerial attention should be paid to the crop production side of the business. Amendments to the regulations governing fertiliser application would help to improve the situation. Any monitoring of the situation must include an effective and exact controlling of the amount of fertiliser applied to any given area. The legal obligations for recording fertilisation set out in the present German regulations (Düngeverordnung DÜV, 2007) do not fulfil this need.

\section{REFERENCES}

Aarnink AJA, Verstegen MWA (2007). Nutrition, key factor to reduce environmental load from pig production. Livest. Sci. 109(1-3):194203.

Abdalla CW (2002). The Industrialization of Agriculture: Implications for Public Concern and Environmental Consequences of Intensive Livestock Operations. Penn State Environ. Law Rev. 10:175-191.

Berkhoff K (2005). Nutrient modelling in an area of intensive livestock husbandry - facing the demands of the WFD. In Proceedings of the International Conference "Multifunctionality of landscapes", May 1819, 2005, Justus-Liebig University Gießen, Germany. P. 88.

Basset-Mens C, van der Werf HMG (2005). Scenario-based environmental assessment of farming systems: the case of pig production in France. Agric. Ecosyst. Environ. 105(1-2):127-144.

BodSchätz G (2007). Gesetz zur Schätzung des landwirtschaftlichen Kulturbodens (Bodenschätzungsgesetz - BodSchätz G) [Law for the estimation of agricultural crop land] (BGBI. I pp. 3150-3176.

Bosshard A (2000). A methodology and terminology of sustainability assessment and its perspectives for rural planning. Agric. Ecosyst. Environ. 77:29-41. 
Breeuwsma A, Reijerink JGA, Schoumans OF (1995) Impact of manure on accumulation and leaching of phosphate in areas of intensive livestock farming. In: K. Steele (ed.), Animal waste and the landwater interface. Boca Raton (USA), Lewis. pp. 239-249.

Builtjes $P$, Hendriks $E$, Koenen $M$, Schaap $M$, Banzhaf $S$, Kerschbaumer A, Gauger T, Nagel H-D, Scheuschner T, Schlutow A (2011) Erfassung, Prognose und Bewertung von Stoffeinträgen und deren Wirkung in Deutschland. UBA 38/2011 ISSN. pp. 1862-4804.

Cahoon LB, Mikucki JA, Mallin MA (1999). Nitrogen and phosphorus inputs to the Cape Fear and Neuse River Basins to support intensive livestock production. Environ. Sci. Technol. 33(3):410-415.

Dämmgen U (2009). Calculations of emission from German agriculture National Emission Inventory Report (NIR) 2009 for 2007. VTI Agric.Forest. Res, ISNB 978-3-86576-049-4, pp. 9-5.

De Boer IJ, Peters HT, Grossman M, Koops WJ (1997). Nutrient flows in agriculture in The Netherlands with special emphasis on pig production. J. Anim. Sci. 75(8):2054-2063.

DIN 19684 (2000). (Deutsches Institut für Normung eV) [German Institute for Standardisation] (2000) Methods of soil investigations for agricultural water engineering - Chemical laboratory tests - Part 3: Determination of the loss on ignition and the residue of soil after ignition, Beuth Verlag, Berlin, Germany.

DIN 38414 (1985) Deutsches Institut für Normung eV (DIN) [German Institute for Standardisation] (1985) German standard methods for the examination of water, waste water and sludge; sludge and sediments (group S); determination of leachability by water, Beuth Verlag, Berlin, Germany.

Dourmad JY, Guingard N, Latimier P, Seve B (1999). Nitrogen and phosphorus consumption, utilisation and losses in pig production: France. Livest. Prod. Sci. 58(3):199-211.

Düngeverordnung - DüV (2007). Verordnung über die Anwendung von Düngemitteln, Bodenhilfsstoffen, Kultursubstraten und Pflanzenhilfsmitteln nach den Grundsätzen der guten fachlichen Praxis [German Fertilizer Ordinance]. BGBI. I S. 221.

Fernandez JA, Poulsen HD, Boisen S, Rom HB (1999). Nitrogen and phosphorus consumption, utilisation and losses in pig production: Denmark. Livest. Prod. Sci. 58(3):225-242.

Fleischer E (1998). Nutztierhaltung und Nährstoffbilanzen in der Landwirtschaft [Livestock husbandry and nutrient audits in agriculture]. Angewandte Umweltforschung 10. Analytica 1998, ISBN 3-929342-29-4.

Gesellschaft für Ernährungsphysiologie (GfE) (2006) Energie- und Nährstoffbedarf landwirtschaftlicher Nutztiere [Energy and nutrient requirements of farm animals]. DLG-Verlag, ISBN 978-3-7690-06834.

Ilea RC (2009). Intensive Livestock Farming: Global Trends, Increased Environmental Concerns, and Ethical Solutions. J. Agric Environ. Ethics 22(2):153-167.

ISO 11732, ISO 11885: Internationale Organisation für Normung (ISO) (2005). [International Organisation for Standardisation]. Water quality -- Determination of selected elements by inductively coupled plasma optical emission spectrometry (ICP-OES). ICS:13.060.50.

Koelsch R, Lesoing G (1999). Nutrient balance on Nebraska livestock confinement systems. J. Anim. Sci. 77:63-71.

Mc Sweeny WT, Shortle JS (1989): Water Quality Protection in Intensive Livestock Areas: Policy Implications of Alternative Producer Behavior. Northw. J. Agric. Resour. Econ. 18(1):1-11.
Nielson AH, Kristensen IS (2005). Nitrogen and phosphorus surpluses on Danish dairy and pig farms in relation to farm characteristics. Livest. Prod. Sci. 96:97-107.

Niedersächsisches Ministerium Ernährung, Landwirtschaft, Verbraucherschutz und Landesentwicklung [Ministry of Food, Agriculture, Consumer Protection and Regional Development, Lower Saxony] (2012). Förderung extensiver Produktionsverfahren Ausbringen von flüssigem Wirtschaftsdünger auf Acker- oder Grünland mit besonders umweltfreundlichen Ausbringungsverfahren. (Niedersächsische und Bremische Agrarumweltprogramm) 2012 A3 [Advancement of intensive methods of production - application of liquid manure on fields and grass land using environmentally friendly application methods (Agri-environmental program for Lower Saxony and Bremen 2012 A3).

Luft TA (2002). Technische Anleitung zur Reinhaltung der Luft (TA Luft) [Technical Instructions on Air Quality Control]: Erste Allgemeine Verwaltungsvorschrift zum Bundes-Immissionsschutzgesetz. [First General Administrative Regulation Pertaining to the Federal Immission Control Act] Bundesministerium für Umwelt, Naturschutz und Reaktorsicherheit [German Federal Ministry for Environment, Nature Conservation and Nuclear Safety], Carl Heymanns Verlag, Berlin.

Tamminga S (2003). Pollution due to nutrient losses and its control in European animal production. Livest. Prod. Sci. 84:101-111.

Tilman D, Cassman KG, Matson PA, Naylor R, Polasky S (2002) Agricultural sustainability and intensive production practices. Nature 418:671-677.

Van der Peet-Schwering CMC, Jongbloed AW, Aarink AJA (1999). Nitrogen and phosphorus consumption, utilisation and losses in pig production: The Netherlands. Livest. Prod. Sci. 58 (3):213-224.

VDLUFA (1991). Verband Deutscher Landwirtschaftlicher Untersuchungs- und Forschungsanstalten (VDLUFA) [Association of German Agricultural Analytic and Research Institutes]. Methodenbuch Band I, Die Untersuchung von Böden [Method Handbook 1: Soil investigations] 4th edition, ISBN 978-3-941273-139.

Warnecke SM, Biberacher H-J, Brauckmann Broll G (2009). Regionally optimised animal farm manure transports in an area with high intensity animal farming systems. In: Van Ittersum MK, Wolf $\mathrm{J}$, Van Laar $\mathrm{HH}$ (eds) Proceedings of the "Conference on Integrated Assessment of Agriculture and Sustainable Development: Setting the Agenda for Science and Policy (AgSAP 2009)". Egmond aan Zee, The Netherlands, 10-12 March 2009. Wageningen University and Research Centre, Wageningen, pp. 312-313, ISBN 978-90-8585-4012.

Wing S, Wolf S (2000). Intensive livestock operations, health, and quality of life among eastern North Carolina residents. Environ. Health Perspect. 108(3):233-238. 